\title{
Dermatomyositis Associated with Laryngeal Rhabdomyosarcoma: A Case Report
}

\author{
Larenks Rabdomyosarkomu ile İlişkili Dermatomyozit: Olgu Sunumu \\ Gökçe SAYGI UYSAL, Murat ÖZCAN, Sabri KÖSEOĞLU, Mehmet Ali ÇETIN, Hüseyin DERE \\ Department of Otolaryngology, Ankara Numune Training and Research Hospital, Ankara, Turkey
}

Dermatomyositis is a systemic autoimmune inflammatory disorder which is characterized by cutaneous manifestations and associated with various types of malignancies. Rhabdomyosarcoma is a rapidly growing, malignant mesenchymal neoplasm which arises from primitive muscle cells known as rhabdomyoblasts. The head and neck are the primary sites for rhabdomyosarcoma. To the best of our knowledge, concurrent dermatomyositis and rhabdomyosarcoma have not been reported before. In this article, we present a case with dermatomyositis and laryngeal rhabdomyosarcoma who was treated with surgery and chemoradiotherapy.

Key words: Dermatomyositis; larynx; sarcoma.

Rhabdomyosarcoma (RMS) is a rapidly growing, malignant mesenchymal neoplasm that arises from primitive muscle cells called rhabdomyoblasts and accounts for $15-20 \%$ of all soft tissue sarcomas. ${ }^{[1]}$ In fact, in pediatric patients, RMS accounts for up to $50 \%$ of all soft tissue tumors. ${ }^{[2]}$

The head and neck are the primary sites for RMS in children and teenagers followed by the genitourinary tract, limbs, thorax, and retroperitoneum, but it can be found anywhere in the body. Hawkins et al. ${ }^{[3]}$ reported that the head and neck account for $24 \%$ of all RMS sites.

In the head and neck, RMS may appear in the orbit, nasopharynx, nasal cavity, paranasal sinuses,
Dermatomyosit kütanöz bulgularla karakterize olan sistemik, otoimmün, inflamatuvar ve çeşitli malignite tipleri ile ilişkili bir hastalıktır. Rabdomyosarkom, rabdomyoblast olarak adlandırılan primitif kas hücrelerinden köken alan ve hızlı büyüyen malign mezenkimal bir neoplazidir. Rabdomyosarkom en sık baş ve boyun bölgesinde görülmektedir. Bilgimiz dahilinde dermatomyozit ve larengeal rabdomyosarkom birlikteliğine literatürde rastlanmamıştır. Bu makalede, cerrahi ve kemoradyoterapi ile tedavi edilen dermatomyozit ve larengeal rabdomyosarkom birlikteliği olan bir olgu sunuldu.

Anahtar sözcükler: Dermatomyozit; larenks; sarkom.

temporal bone, pterygopalatine fossa, infratemporal fossa, and other sites, ${ }^{[4]}$ but in less than $3 \%$ of the cases, it has also been found in the larynx. In addition, orbital lesions have a better prognosis than the other locations. ${ }^{[5]}$

Dermatomyositis (DM) is a systemic autoimmune inflammatory disease with characteristic cutaneous manifestations. It was first described in 1887 , and both children and adults are affected. ${ }^{[6]}$ The muscles, skin, vessels, joints, gastrointestinal tract, cardiac tissues, and lungs can be involved, ${ }^{[6]}$ and it is well known that DM is associated with various types of cancer. The coexistence rate of a malignancy with DM has varied widely in the literature (6-60\%). This is

Received: July 31, 2012 Accepted: November 26, 2012

Correspondence: Gökçe Saygı Uysal, M.D. Ankara Numune Eğitim ve Araştırma Hastanesi Kulak Burun Boğaz Hastalıkları Kliniği, 06230 Altındağ, Ankara, Turkey. Tel: +90 505 - 8751650 e-mail: gcsaygi@gmail.com

C2013 Turkish League Against Rheumatism. All rights reserved. 
most likely because comprehensive studies are lacking on this topic and the fact that those reports focused on different regions in the various patients. ${ }^{[7,8]}$

Malignancy can occur before, after, or at the same time as the onset of myositis, and it has been reported that the malignancy risk is highest in the first 3-5 years after the diagnosis of this condition. ${ }^{[9]}$

In addition, only a few case reports have been published concerning the association of sarcomas and DM, making it a rare event. ${ }^{[10,11]}$ Dermatomyositis that is linked with cancer is generally resistant to corticosteroids and cytotoxic therapies, and this activity reflects the state of the cancer. Some reports also exist that have described an improvement in DM without immunosuppressive drugs after resection of the cancers.

This case report presents a patient with DM and laryngeal RMS who was treated with surgery, chemotherapy, and radiotherapy. To our knowledge this is the first reported case of concurrent DM and RMS in a patient.

\section{CASE REPORT}

A 59-year-old man was admitted to our clinic with a six-week history of intermittent alteration in his voice quality. He had no history of sore throat or the feeling of a lump in his throat and had no symptoms suggesting laryngopharyngeal reflux. The patient had smoked one pack of cigarettes per day for 25 years and had been diagnosed with dermatomyositis six months prior to his admission after undergoing a skin biopsy.

A videolaryngoscopic examination showed a $5 \times 5 \mathrm{~mm}$ polypoid mass at the posterior commissure (Figure 1). However, the pyriform fossae, other vocal cord, epiglottis, and valleculla were normal. Computed tomography (CT) of the larynx showed an irregularity at the posterior commissure, but there was no nodal involvement or evidence of metastasis on the thoracic CT.

The patient was hospitalized and treated with prednisolone for his DM because surgery could not be performed until his general condition became suitable for general anesthesia.

After the medical therapy for DM, a direct laryngoscopy was performed, and the lesion was totally excised. A histological examination showed that the cells were strongly positive for desmin and vimentin and also focally positive for myogenin. However, they were negative for CD-34, BCL-2,
CD-99, pan-cytokeratin (pan-CK), cytokeratin, HMB-45 (a melanocytic cell-specific monoclonal antibody), and S-100 protein as well as the leucocyte common antigen (LCA) and, epithelial membrane antigen (EMA). Additionally, a few cells were positive for actin. A histological examination of the specimen confirmed the diagnosis of RMS.

After surgery, the patient was referred to medical and radiation oncologists who recommended chemotherapy and radiotherapy. The chemotherapy procedure included four cycles of ifosfamide, mesna, and doxorubicin (Adriamycin) (IMA) followed by radiotherapy at $200 \mathrm{cGy} /$ day for a total of $6000 \mathrm{cGy}$. Thus far, the patient has undergone monthly follow-up visits, which include a clinical examination and videolaryngoscopy, and remains free of disease 18 months after the histological diagnosis.

\section{DISCUSSION}

The larynx is an uncommon site for sarcomas. Glick ${ }^{[12]}$ first described a case of laryngeal RMS in 1944. In addition, laryngeal pleomorphic RMS is found more frequently in males. ${ }^{[13]}$

The literature on laryngeal RMS indicates that the tumor tends to originate in the vocal cord region and appears as a polypoid mass which may extend above and below the vocal cords. ${ }^{[14]}$ In our case, there was a $5 \times 5 \mathrm{~mm}$ polypoid lesion at the posterior commissure.

Since the clinical findings and macroscopic appearance of RMS are the same as other laryngeal neoplasms, the histopatological and

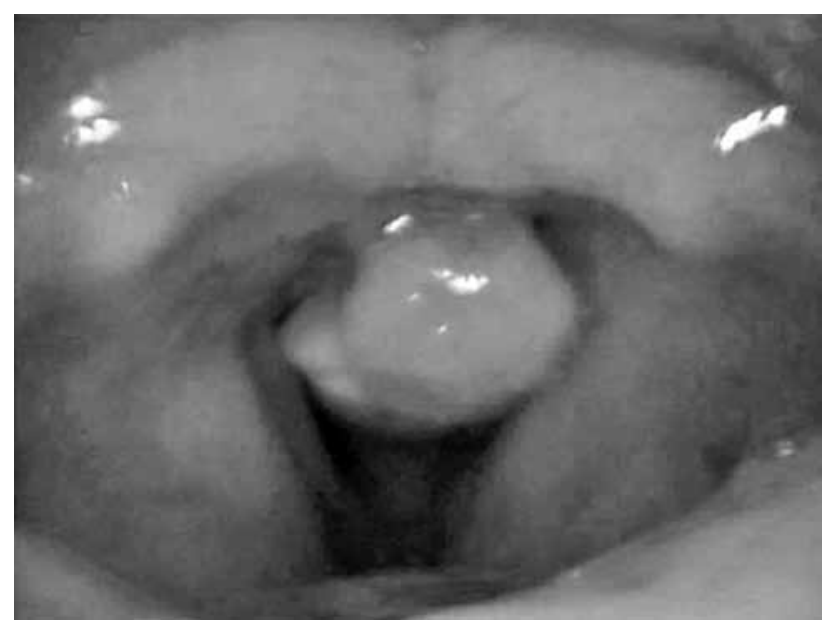

Figure 1. A videolaryngoscopic examination showed a $5 \times 5 \mathrm{~mm}$ polypoid mass at the posterior commissure. 
immunohistochemical examinations are crucial for diagnosis, ${ }^{[14]}$ and in our case, the definitive diagnosis was established through these means.

Rhabdomyosarcoma is treated by a combination of surgery, chemotherapy, and radiation, with the most frequently used chemotherapy agents being vincristine, cyclophosphamide, dactinomycin, adriamycin, ifosfamide, and virion protein VP-16 (etoposid). The use of adjuvant chemotherapy with radiotherapy is gaining popularity because it reduces the need for mutilating surgery in the head and neck due to RMS. ${ }^{[15]}$

After surgery, our patient was treated with four cycles of IMA and radiotherapy at $200 \mathrm{cGy} /$ day for a total of $6000 \mathrm{cGy}$. However it is not clear if this treatment modality has any significant effect on the outcome in adult laryngeal disease since only a few cases have been reported.

Dermatomyositis is an idiopathic, chronic, inflammatory myopathy characterized by cutaneous findings. It primarily affects the skin and the muscles but may also affect other organ systems. In addition, DM frequently affects the joints, esophagus, lungs, and, less commonly, the heart. ${ }^{[16]}$

The malignancy rate of DM is up to $10 \%$ and is more common in adults over the age of 60 as well as in the first five years after diagnosis. ${ }^{[17]}$ Our patient was a 59-year-old man with only a six-month history of DM.

Sigurgeirsson et al. ${ }^{[8]}$ reported that had they detected 61 malignancies in 59 of 392 DM patients either at the same time as the diagnosis or afterwards and that the malignancy rate was higher in women than men.

Uterine carcinosarcoma and soft tissue sarcoma of the stomach were also reported to be associated with DM..$^{[10,11]}$ Furthermore, Şendur et al. ${ }^{[10]}$ reported a case with soft tissue sarcoma of the stomach and $\mathrm{DM}$, and Chandiramani et al. ${ }^{[1]]}$ reported DM as a paraneoplastic syndrome that developed in a patient with uterine carcinosarcoma.

However, as far as we know, there have been no cases of DM associated with laryngeal RMS in the literature, and our patient was the first to have DM with laryngeal RMS and be treated successfully.

The five-year survival rate ranges between 30\% for patients with metastasis at presentation, but it increases to $80 \%$ when the disease is localized so that complete resection can be performed. ${ }^{[18,19]}$ Today, our patient remains free of disease 18 months after the histological diagnosis.

\section{In conclusion}

In cases involving DM, laryngeal malignancy should be kept in mind. These patients should be questioned carefully regarding the presence of hoarseness, dysphagia, and dyspnea. Together with these complaints, asymptomatic patients should be examined by an otolaryngologist. In addition, the nasopharynx, larynx, and hypopharynx should be examined endoscopically, and a biopsy should be planned for any suspicious lesions.

\section{Declaration of conflicting interests}

The authors declared no conflicts of interest with respect to the authorship and/or publication of this article.

\section{Funding}

The authors received no financial support for the research and/or authorship of this article.

\section{REFERENCES}

1. Russell WO, Cohen J, Enzinger F, Hajdu SI, Heise H, Martin RG, et al. A clinical and pathological staging system for soft tissue sarcomas. Cancer 1977;40:1562-70.

2. Arndt CA, Crist WM. Common musculoskeletal tumors of childhood and adolescence. N Engl J Med 1999;341:342-52.

3. Hawkins WG, Hoos A, Antonescu CR, Urist MJ, Leung $\mathrm{DH}$, Gold JS, et al. Clinicopathologic analysis of patients with adult rhabdomyosarcoma. Cancer 2001;91:794-803.

4. Kraus DH, Saenz NC, Gollamudi S, Heller G, Moustakis M, Gardiner S, et al. Pediatric rhabdomyosarcoma of the head and neck. Am J Surg 1997;174:556-60.

5. Sercarz JA, Mark RJ, Nasri S, Wang MB, Tran LM. Pediatric rhabdomyosarcoma of the head and neck. Int J Pediatr Otorhinolaryngol 1995;31:15-22.

6. Nagaraju K, Plotz PH, Miller FW. Etiology and pathogenesis of inflammatory muscle disease. In: Hochberg MC, Silman AJ, Smolen JS, Weinblatt ME, Weisman MH, editors. Rheumatology. Vol. 2. 3rd ed. New York: Mosby; 2003. p. 1523-36.

7. Till SH, Jones AC. Dermatomyositis--how far to go! Ann Rheum Dis 1998;57:198-200.

8. Sigurgeirsson B, Lindelöf B, Edhag O, Allander E. Risk of cancer in patients with dermatomyositis or polymyositis. A population-based study. N Engl J Med 1992;326:363-7.

9. Buchbinder R, Forbes A, Hall S, Dennett X, Giles G. Incidence of malignant disease in biopsy-proven inflammatory myopathy. A population-based cohort study. Ann Intern Med 2001;134:1087-95.

10. Sendur MA, Aksoy S, Yaman S, Arik Z, Kilinç L, Zengin N. Dermatomyositis complicated with a soft tissue sarcoma. Rheumatol Int 2012;32:3329-30. 
11. Chandiramani M, Joynson C, Panchal R, Symonds RP, Brown LJ, Morgan B, et al. Dermatomyositis as a paraneoplastic syndrome in carcinosarcoma of uterine origin. Clin Oncol (R Coll Radiol) 2006;18:641-8.

12. Glick HN. An unusual neoplasm in the larynx of a child (rhabdomyosarcoma). Ann Otol Rhinol Laryngol 1944;53:699-704.

13. Pittore B, Fancello G, Cossu Rocca P, Ledda GP, Tore G. Rhabdomyosarcoma: a rare laryngeal neoplastic entity. Acta Otorhinolaryngol Ital 2010;30:52-7.

14. Robin PE, Olofsson J. Tumours of the Larynx. In: Hibbert J, editor. Laryngology and head and neck surgery, ScottBrowns Otolaryngology. 6th ed. Oxford: ButterworthHeinemann (A division of Reed Educational and Professional Publishing Ltd.); 1997. p. 1-43.
15. Ruymann FB, Grovas AC. Progress in the diagnosis and treatment of rhabdomyosarcoma and related soft tissue sarcomas. Cancer Invest 2000;18:223-41.

16. Callen JP, Wortmann RL. Dermatomyositis. Clin Dermatol 2006;24:363-73.

17. Zhang W, Jiang SP, Huang L. Dermatomyositis and malignancy: a retrospective study of 115 cases. Eur Rev Med Pharmacol Sci 2009;13:77-80.

18. Abali H, Aksoy S, Sungur A, Yalçin S. Laryngeal Involvement of Rhabdomyosarcoma in an Adult. World J Surg Oncol 2003;1:17.

19. Moretti G, Guimarães R, Oliveira KM, Sanjar F, Voegels RL. Rhabdomyosarcoma of the head and neck: 24 cases and literature review. Braz J Otorhinolaryngol 2010;76:533-7. 